Article

\title{
Ecological Analyses of Social Sustainability for International Production with Fixed and Moveable Technologies
}

\author{
Stephen Fox ${ }^{1, *}$, Yusuf Mubarak ${ }^{2}$ and Abdurasak Adam ${ }^{3}$ \\ VTT Technical Research Centre of Finland Ltd., P.O. Box 1000, 02044 Espoo, Finland \\ 2 Finland-Somalia Association, Siltasaarenkatu 4, 00530 Helsinki, Finland; yusuf.m.mubarak@gmail.com \\ 3 Finnish-Somali Business Council, P.O. Box 1023, 00101 Helsinki, Finland; abdurasakadam@gmail.com \\ * Correspondence: stephen.fox@vtt.fi; Tel.: +358-40-747-8801
}

Received: 23 August 2020; Accepted: 13 October 2020; Published: 14 October 2020

\begin{abstract}
Mutualism is an ecological concept. Mutualistic relationships are mutually beneficial. However, as found in development geography studies, relationships between different peoples in different parts of the world are often not mutually beneficial. For example, there is lack of mutualism in international production that is dominated by companies that dictate where production is and is not carried out. This lack of mutualism leaves many other countries with little production capacity and persistent widespread unemployment. Thus, international production is not characterized by mutualistic social sustainability. International production has long been framed as being an ecological phenomenon that requires ecological analyses. However, previous social sustainability studies concerned with production have not provided ecological analyses of social sustainability. Rather, previous studies have focused on social theory and related operational practices. By contrast, in this paper, findings are reported from action research concerned with facilitating mutual prosperity growth between a Northern-European country, Finland, and an African fragile state, Somalia. The action research encompassed business development processes and moveable production technologies for mutual prosperity growth between the two countries. Ecological analyses, which were carried out during the action research, are provided of current international production and alternative production with moveable production technologies.
\end{abstract}

Keywords: development geography; ecological fitness; ecosystem engineering; moveable production technologies; socially sustainable international production; world-class production; world-fit production

\section{Introduction}

Relationships between different peoples in different parts of the world are often not mutually beneficial [1-3]. Notably, many relationships in the current international production of physical goods are often not mutually beneficial. International production involves processes such as extraction of raw materials, conversion of raw materials into formed materials, manufacturing of components from formed materials, and assembly of products from components. Often, different production processes, such as materials extraction and product assembly, take place in different countries. Currently, production is reducing in many countries as dominant production companies determine where production processes will be carried out and where production processes will not be carried out $[4,5]$. This includes countries such as Finland, which can lose long-established production capabilities, and countries such as Somalia that can be hindered in development of their own production capabilities. 
Internationally dominant production companies can be characterized as having world-class productivity, quality, etc., and it has been argued that world-class production can be sustainable [6-8]. However, the dominance of world-class manufacturers is not socially sustainable internationally because, by limiting where production is carried out, it brings the harms of limiting the generation of employment and provision of essential goods in many parts of the world [9-11]. Indeed, rather than current international relationships being socially sustainable, some have even been framed as neo-colonialism [12,13]. Hence, new perspectives are needed to improve analyses of international production's social sustainability. Accordingly, in this paper, reference is made to ecology science in analyses of the social sustainability of international production. In particular, the social sustainability of international production with fixed production technologies is compared to the social sustainability of international production with moveable production technologies. In doing so, the following constructs from ecology science are applied: ecological fitness, ecosystem engineering, energetics, mobile linking organisms, mutualism, and scalable sustainability.

Overall, findings are reported in this paper from action research carried out between 2013 and 2020. Specifically, action research concerned with the development of socially sustainable mutual prosperity growth between Finland and Somalia. Findings are reported in the six remaining sections of the paper. In Section 2, the research methodology is described. In Section 3, the literature review is presented. In Section 4, the action research is reported. In Section 5, ecological analyses are provided. In Section 6, implications and directions for further research are discussed. In Section 7, conclusions are stated.

\section{Methodology}

\subsection{Objectives}

Action research adds the goal of change to the traditional research goals of improving explanation and prediction [14]. The focus of change was business interactions between Finland and Somalia. In 2013, there was a lack of procedures in place to facilitate business interactions and there was very little business interaction between the two countries. Accordingly, the objectives of the action research were to bring about two interrelated changes. They are (i) to introduce business interaction procedures that are accessible to both Finnish companies and Somali companies, which then (ii) lead to increased mutualistic business interactions between the two countries that can generate employment in both countries and increase the provision of essential goods in Somalia. Thus, the objectives of the action research were directed to addressing harms in current international production, which is dominated by world-class manufacturers that decide where and where not production will be carried out.

The first and second authors began the action research. It did not begin with a pre-stated hypothesis of how these objectives would be achieved. Rather, the action research evolved towards the fulfilment of its objectives step-by-step, with each step opening up possibilities for next steps as circumstances changed over the years in both countries. Step-by-step action research that progresses towards change objectives without pre-stated hypotheses is congruent with evolutionary uncertainty in both ecology and economics that limits predictability and, hence, limits what can be pre-stated $[15,16]$. Here, it is congruent with the evolving uncertainty of Somalia's ecology and its economy [17]. At each stage, rather than define a hypothesis, the first and second authors considered whether or not to proceed further based on whether or not progress was being made towards the objectives, and what more could be done to progress towards the objectives.

\subsection{Scope: Finland and Somalia}

The action research encompassed Finland and Somalia. This is appropriate for action research concerned with change towards socially sustainable mutual prosperity growth between countries. It is appropriate because both countries are affected by the concentration of global manufacturing elsewhere, and because both seek sustainable industrial development. Finland seeks to maintain or 
improve its industrial competitiveness [18], while Somalia seeks to develop new industrial capacity, for example, to address its systemic trade deficit in manufactured goods [19]. It is also appropriate for action research concerned with change towards socially sustainable mutual prosperity growth between rich and poor countries because the two countries are at opposite ends of fragility rankings. In particular, these countries are separated by 176 positions in the Fragile States Index for 2019. Specifically, Finland is ranked to be the least fragile country in 2019, while Somalia is ranked to be the second most fragile country in 2019 [20]. Thus, Finland and Somalia provide an appropriate and challenging scope for action research concerned with development of socially sustainable mutual prosperity growth between countries. Furthermore, overcoming challenges in establishing mutualism between Finland and Somalia can provide insights for other rich and poor countries that also have different cultures and different languages, as well as very different levels of fragility.

\subsection{Methods}

The action research included actions such as arranging matchmaking events in Finland and in Somalia. Matchmaking events involved Finnish companies and Somali companies. Actions also included the setting up of a membership association: the Finnish-Somali Business Council (FSBC). This involved many interrelated actions, including developing the FSBC's procedures, defining its membership requirements, setting up its website, and composing website content in three languages: English, Finnish, and Somali. The action research also encompassed survey research, which included multi-vocal literature reviews and unstructured interviews. Multi-vocal literature reviews encompass scientific literature and documents not controlled by academic publishing such as online reports from non-governmental organizations [21]. For example, reference was made to the latest online reports about the Somalia socio-economic situation.

Also, survey research included interviews with an emergent purposive sample of participants. This is a type of nonprobability sample, which is formed by making purposive sampling decisions during the research as the researcher's topic knowledge increases and/or as events relevant to the topic unfold [22]. Emergent purposive sampling in this action research involved contact being made with chambers of commerce in Finland and Somalia in order to identify business people with interest establishing business between the two countries. This is congruent with the goal of action research being to go beyond traditional research goals of improving explanation and prediction of causation to the goal of changing causal variables to bring new effects [14]. The informant style of unstructured interview was used, within which interviewers do not seek to control the interviews but rather enable the interviewees to express the full range of their expert opinions about what is relevant to the topic [23].

Participants in the action research included representatives from a total of 49 Finnish companies and representatives from 56 Somali companies. The sample size was not planned in advance. Rather, as many companies as possible were sought to participate in accordance with the action research objective of increased mutualistic business relationships between the two countries. The companies who participated are not representative of companies in the two countries. They are representative of companies that are interested in international business in what to them are new markets. In particular, the Finnish companies are representative of the very few companies that are interested to do business in a fragile state, which is depicted in popular media as being a place of violent instability [24]. Interviews were conducted by the second author and third author in Finnish language or Somali language as appropriate.

As described in detail in Section 4, the action research was carried out in three phases between 2013 and 2020. Progress made during the action research encouraged deeper analyses of how the ecological concepts can be related to social sustainability in international production. Hence, the ecological analysis presented in Section 5 was carried out by the first author at the end of third phase of the action research. Approximately 2300 person hours were expended over the three phases by the three authors, with $20 \%$ of person hours being spent during the first phase, $70 \%$ during the second phase, and the remainder during the third phase. 


\section{Literature Review}

From an ecological perspective, relationships range from to mutualism (i.e., beneficial/beneficial) to parasitism (i.e., beneficial/harmful) [1]. However, relationships between different peoples in different parts of the world are often not mutualistic [2,3]. For example, it has been argued that the development of some countries leads to the underdevelopment of other countries and even the underdevelopment of regions with many countries $[25,26]$ In particular, it has been argued that resources flow from what have been described as peripheral countries to what have been described as core countries. Within this conceptualization, work in peripheral countries is low-skill and labor-intensive during the extraction of raw materials for export to core countries that carry out world-class, high-skill, capital-intensive production. It is argued that this world system leads to core countries being enriched at the expense of peripheral countries, and peripheral countries being dependent on core countries. It is recognized that this world system has dynamics in which countries can move from being the most dominant core country to a less important core country and even being a semi-peripheral country [27]. For example, it can be argued that the most dominant core country has changed in recent centuries from the Netherlands to the United Kingdom to the United States, and may now be changing to China. Nonetheless, it can be argued that whatever country is the dominant core country, other countries continue to be peripheral and dependent $[28,29]$. As such views are focused on the fundamentally material nature of physical production, such as the local extraction and global movement of raw materials, production in this world system has been framed as being an ecological phenomenon that requires ecological analyses [30-33].

However, ecological analyses have not been carried out previously in relation to social sustainability within current international production. Rather, previous social sustainability studies have referred to social theory [34] including social exchange theory, stakeholder theory, structuration theory, and transaction cost economics [35]. There is no one universally agreed precise definition of social sustainability in the international production of physical goods. However, previous studies concerned with social sustainability in physical production have often drawn attention to operational factors. These include ergonomics, health and safety, training, and work-life balance [36]. Other social sustainability studies in production have drawn attention to the importance of reciprocity and trust [37], while others have drawn attention to a wider range of factors including diversity, learning, and self-organization [38]. Social sustainability studies in the management of industrial supply chains have highlighted the importance of numerous factors, including community influence, contractual stakeholders influence, health, training, and safety [39]. Other factors identified as being important for social sustainability in industrial supply chains are diversity, health, labor rights, product responsibility, safety, and societal responsibility [40]. Thus, despite the fundamentally material nature of physical production, there has been little consideration of the need for ecological analyses of social sustainability.

\section{Mutualistic Business Relationships}

\subsection{First Phase: Starting 2013}

Driven mainly by the second author, the Finland-Somalia Association (FSA) promoted interaction between Somali companies and Finnish companies. FSA is a non-government friendship association. A match-making event was held during August 2016 in Finland involving 25 Finnish companies and 14 Somali companies. Subsequently, one Finnish company signed a collaboration agreement with a Somali company. A second match-making event was held during October 2017 in Finland, where there were 23 Finnish companies and 18 Somali companies. Subsequently, four Finnish companies visited Somalia. There was overlap in attendance at these two matchmaking events with some companies attending both and but some other companies attending only one of them. The two match-making events were followed by a consultative meeting in December 2017, during which it was agreed to form a Finnish-Somali Business Council (FSBC) as a membership association. The purpose of the FSBC being to support the coordination and cooperation of Finnish companies and Somali companies that register 
as members. The third author represents FSBC in Somalia. During this phase, it became apparent that Finnish companies were developing moveable technological solutions relevant to Somalia.

\subsection{Second Phase: Starting 2018}

From the beginning of 2018 until February 2019, a project was carried out that involved implementation of a formal process for match-making in the following four stages. First, Finnish companies register interest for doing business in Somalia by providing information about what kind of collaboration they would like in Somalia. Then, relevant Somali companies are identified for collaboration and register their interest. Next, companies are introduced to each other. Subsequently, Finnish companies can apply for partial funding to carry out feasibility studies in Somalia. During or after the feasibility study stage, collaboration can begin through usual business practices such as signing agreements. Milestones in the project were a consultative meeting in Finland during January 2018, which was followed by a consultative meeting in Somalia during January 2019 where there were 20 Finnish companies and 30 Somali companies. There was overlap between companies that participated in these meetings and those that had participated in previous meetings. Overall, the project enabled refinement and dissemination of the match-making procedure, which has continued to be operated successfully. During this phase, connections were initiated between Finnish companies developing moveable technological solutions and Somali companies.

\subsection{Third Phase: Starting 2019}

In order to explore the potential for wider collaboration, a field study in Somalia was carried out from November 2019 and January 2020. This involved the second and third authors meeting with representatives from 10 Somali companies. During the course of doing so, it became apparent that the Somali agri-food sector is benefiting from business-to-consumer (B2C) entrepreneurship. This includes establishment of new hotels with one or more restaurants, new catering outlets such as cafes, and increased retailing. Interestingly, retailing includes mounting cold storage facilities onto motorcycles and into vans for agri-food sales ranging from raw fish to chilled desserts. These vehicles are customized by Somali engineering workshops with expertise in vehicle adaptation. In particular, Somalis import a wide range of vehicles for personal and business use, which Somali engineering workshops customize for Somali terrain. However, business-to-business (B2B) entrepreneurship in agriculture is hindered fragmentation brought about by extreme events in climate and conflict. During this phase, the usefulness of several different types of Finnish moveable production technologies across individual Somali value chains was recognized. These include moveable water sanitation, mobile factories, and portable cold chain technologies. It was found in this phase of the research that there is an expanding range of mechanical engineering skills in Somalia that are very relevant to fabrication of moveable production technologies such as mobile factories. Thus, there is potential for more fabrication work to be carried out in Somalia by Somalis.

\section{Ecological Analysis}

\subsection{Current International Production}

The causal diagram [41,42] in Figure 1 summarizes that production at few physical locations undermines the international social sustainability of international production. The causal variables shown in Figure 1 are indicative of social sustainability issues found to be important in previous studies by others [36-40]. Consider, for example, how increasing the sophistication of production can contribute to the concentration of physical production in a reducing number of locations. For example, Industry 4.0 involves applying cyber-physical systems to production in addition to automation from Industry 3.0, assembly lines from Industry 2.0, and mechanization from Industry 1.0 [43,44]. Such highly sophisticated production can involve overriding natural evolutionary constraints by drawing natural resources from around the world to a few locations [4,5]. Also, it can override natural 
evolutionary balance of ecological fitness among a wide variety of populations [45] by increasing the number of fitness components needed for survival [46]. For example, from mechanization to assembly lines to automation to cyber-physical systems [47]. Where there is natural evolutionary balance of ecological fitness among a wide variety of populations, it can be expected that a wide variety of populations will survive. By contrast, it can be expected that fewer populations will survive when natural evolutionary balance of equal ecological fitness is lost. For example, current international production reduces international social sustainability $[9,10]$ and reduces the potential for some populations to survive where they have lived for previous generations. Already in 2015 during the Africa-EU Migration Summit in Malta, it was stated that Africa needs to industrialize in order to generate sufficient employment to reduce mass migration [48]. However, lack of international socially sustainable industrialization continues, and mass migration carries on at high human cost [49-51]. Thus, as summarized in Figure 1, the concentration of physical production at few physical locations can undermine causal variables for socially sustainable production internationally.

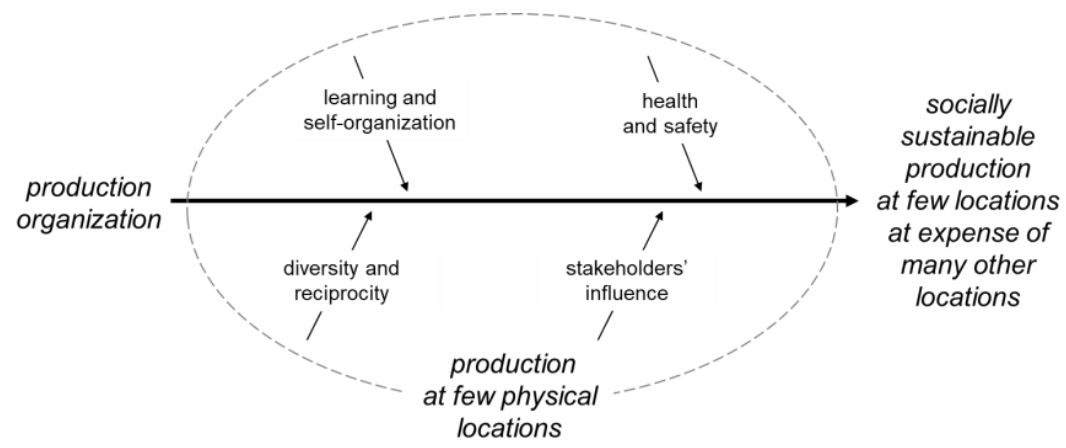

Figure 1. Production is not socially sustainable internationally.

\subsection{Production with Moveable Technologies}

\subsubsection{Moveable Production Systems}

Moveable production technologies can be for a wide variety of off-grid applications including water purification, agricultural production, cold chain, and other innovations in production that leapfrog over the need for capital-intensive fixed industrial infrastructure. Moveable production technologies can be housed in adapted vans, customized lorries, and/or modified shipping containers. Generally, they are enabled by technological advances that make it possible for size, weight, energy consumption, and cost of machines to be reduced. Also, they are enabled by technological advances in renewable energy generation, storage and supply that facilitate off-grid operation [52]. For example, a Finnish company's moveable water sanitation unit is powered by solar arrays. As described in the following sub-sections, from an ecological perspective, moveable productions systems offer several advantages including fostering mutualism.

\subsubsection{Mobile Links}

Mobile linking organisms can enable reorganization and renewal of natural ecosystems after they have been disturbed $[53,54]$. Apropos, there are three challenges arising from the disturbance of Somali agri-food ecosystems by extreme events in weather and conflict [55], which can be addressed by moveable production technologies. These challenges are lack of access to clean water, low productivity, and limited cold chain. In particular, moveable solar-powered water sanitation units are available in shipping containers of different sizes depending upon the volumes of water in need of processing. Also, moveable factories are available for a wide range of agricultural processing. In addition, portable cold chain units are available for transportation in vans and other light-haulage vehicles that are already in use in Somalia. All of the these moveable production technologies can be transported across rough terrain and relocated as necessary in accordance with planned schedules or in response to unexpected 
events due to, for example, weather or conflict. Notably, these three moveable production technologies are independent of each other and can be applied separately by different Somali businesses of different sizes in the renewal and reorganization of Somali agri-food production. Also, like mobile link organisms [54], the diversity of moveable production technology types and their potential interrelations at many different locations enables many new adjacent possibilities for evolution [56]. Importantly, these three moveable production technologies can facilitate B2B development and evolution, which is not dependent upon being initiated by B2C entrepreneurship in catering, hospitality, and retailing. These characteristics of moveable production technologies are very different to manufacturing that involves globally dominant production companies that decide what part of production will be carried out where by whom and then fix the location of production within static buildings [4,5].

\subsubsection{Energetics}

From the point-of-view of energetics [57], energy flows around Somalia are fragmented and are accompanied by energy prices that are among the highest in the world. Also, energy flows tend to be concentrated in and around a few major cities rather than across the whole country. This urban energy concentration is consistent with the concentration of energy flows in fragmented natural ecosystems [58]. By contrast, moveable production systems can increase the scope and the efficiency of energy flows. For example, moveable solar-powered water purification units can capture solar energy at any location where they are moved to and so can bring energy needed in, for example, water purification to any part of Somalia where clean water is required in agri-food or any other type of production. Moreover, energy flows from moveable solar-powered water purification can be combined with energy flows from other moveable production technologies in competitive self-organization and increasing energy flows that characterize healthy ecosystems [59]. These characteristics of moveable production technologies are different to practices of manufacturing in which energy is concentrated in a few locations where fixed production facilities are located.

\subsubsection{Ecosystem Engineering}

Ecosystem engineering involves species changing environments in order to improve their ecological fitness and so increase their own potential for survival [60]. Humans have a long history of taking raw materials from nature and developing ever more sophisticated production processes to convert raw materials into ever more physical goods. The massive impact of human ecosystem engineering has led to the current geological epoch being named the Anthropocene [61]. By contrast, unlike established international production, deployment of moveable production technologies does not require the overriding of natural evolutionary constraints by drawing natural resources from around the world to a few locations. Also, deployment of moveable production technologies does not require overriding the natural evolutionary balance of equal ecological fitness among a wide variety of populations by increasing the number of fitness components needed for survival. Rather, local production by local people using local materials is facilitated. Furthermore, the environmental footprint of production is decreased by reduced need for the disturbance of habitats through the construction of fixed factory buildings and associated roadways, etc.

\subsubsection{Ecological Fitness}

Fitness-maximizing is of fundamental importance for survival [62]. As evident from migration out of Somalia [50], failure to increase fit with environment can result in species, including humans, having to disperse to other environments [63]. Alternatively, as evident from conflict in Somalia, failure to increase fit or to disperse can leave species, including humans, having to respond to threats to survival with basic responses such as fleeing [64]. In any case, humans will tend to strive to survive within the groups that they are included in [65]. Moveable production technologies can increase the ecological fitness of manufacturing by situating production at supply locations when renewable sources are ready to be processed, for example, when local crops are ripe. With regard to inclusive 
fitness, the low cost of moveable production technologies enables them to be owned and operated or leased and operated by a far wider range of groups than those who can find the much larger finances required for conventional industrialization.

\subsubsection{Scalable Sustainability}

In ecological terms, the Somali agri-food sector is a coupled human-natural system [66], within which it is important to balance efficiency needed to minimize resource consumption with flexibility needed to enable adaptation to disturbances [67]. Balance between efficiency and adaptability can support scaling up and long-term sustainability $[68,69]$. Moveable production technologies are efficient because of their self-contained technologies, and they support adaptability in agri-food ecosystems in many different situations. Importantly, moveable production technologies can overcome the common need for adaptability to depend upon having redundancies in networks [70]. This is because moveable production technologies are not facilities that are fixed in size and location, which need to have spare capacity that is usually redundant but can be utilized during exceptional circumstances. Rather, moveable production technologies are mobile and modular and can be moved to wherever adaptation is needed whenever adaptation is needed. These characteristics of moveable production technologies are different to the practices of manufacturing in which efficiency and adaptability are treated as opposing trade-offs rather than compatible characteristics [71].

\subsubsection{Mutualism}

Moveable production technologies support the economics of mutualism [72] between regions that are characterized by stability and that are characterized by fragility. Mutualism involves beneficial relationships for both participants in both regions. This is different to parasitism in which relationships are beneficial for one region but harmful for the other. From the point-of-view of Finnish companies, Somalia provides a valuable market for the moveable production technologies that they develop. From the point-of-view of Somali companies, Finnish moveable production technologies enable them to leapfrog over the high capital costs and high opportunity costs of conventional fixed industrial infrastructure. Moreover, rather than dictate how and where production will be carried out, suppliers of moveable production technologies increase the diversity of how and where production can be carried out. Together, the combination of greatly reduced costs and greatly increased opportunities to create revenue can decrease the generation of debt from regions of high fragility to regions of low fragility. This is different to current international production where many countries that agree to the extraction of their raw material wealth for manufacturing in other countries find themselves with high trade deficits and large foreign debts [12,13]. Figure 2 provides an overview of the analysis.

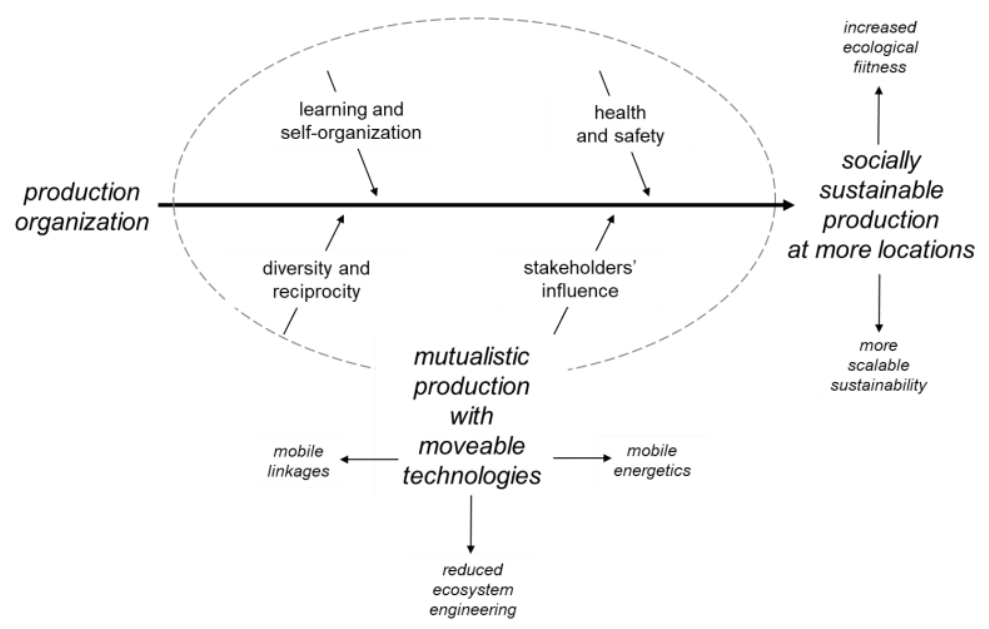

Figure 2. Production can be more socially sustainable internationally with moveable technologies. 


\section{Discussion}

\subsection{Implications from the Research}

Sustainability is often framed as encompassing economic, environmental, and social sustainability [73,74]. Ecological perspectives are often included in assessments of economic sustainability, in what can be described as ecological economics $[75,76]$. Ecological perspectives are inherent to assessments of environmental sustainability and can be expressed in constructs such as ecological footprint $[77,78]$. By contrast, ecological perspectives are less common in assessments of social sustainability and, prior to this paper, have been absent in previous assessments of social sustainability in international production [34-40]. This is despite international production having been framed for many years as being an ecological phenomena that requires ecological analyses [30-33].

It is appropriate that ecological perspectives are included in assessments of social sustainability because human beings and human societies are part of nature. For example, humans, like other species, disperse to other habitats when their former habitat can no longer support them [57,79]. This is evident from human dispersal following deindustrialization when the breakup of industrial communities is followed by the abandonment of industrial communities [80,81]. For humans, dispersal can be based on aspirations [82], and deindustrialization can leave habitats with nothing for people to have aspirations about, other than leaving [83]. Deindustrialization and lack of industrialization are increasingly common throughout the world [84-86] as international production is concentrated among a few dominant manufacturing countries that decide where and where not production will be carried out [4,5]. Hence, human dispersal increases [50,51,87].

As shown in this paper, ecological concepts can be applied in comparative analyses of alternative options for international production. As summarized in Table 1, some of these can be seen as goals, while others can be seen as contributing to the realization of goals. For example, mutual ecological fitness among a wide variety of groups around the world is a goal, while mobile linkages through moveable technologies can contribute to the realization of this goal.

During the research, the applicability of moveable technologies to mutualistic international production became increasingly apparent. Furthermore, through the three phases of the action research there has been increasing diversity amongst participants, and in the range of moveable technologies that have come to be included. This is consistent with ecological mutualism driving the evolution of diversity [88].

More generally, the action research reported in Section 4 provides insights into practices that can contribute to establishing more mutualistic international production that includes countries having very different levels of wealth and stability. In particular, existing non-government friendship associations, such as the Finland-Somalia Association (FSA), can provide a basis for starting mutualistic interactions between countries. Interactions can begin with match-making events between companies. A next step can be to establish an organization that is specifically dedicated to supporting cooperation between companies, such as the Finnish Somali Business Council. At the same time, efforts can be expanded by widening the number of companies involved in both countries through contacting their respective chambers of commerce. Furthermore, procedures can be established to facilitate carrying out feasibility studies to investigate the potential for mutualistic business, which can address harms in current international production such as limiting the generation of employment and provision of essential goods in many parts of the world [9-11]. 
Table 1. Moveable production technologies related to ecological goals and enablers.

\begin{tabular}{|c|c|c|}
\hline & Ecological Concept & Moveable Production Technologies \\
\hline \multirow{3}{*}{ Goals } & Mutualism & $\begin{array}{l}\text { Increase diversity of how and where production can } \\
\text { be carried out through increased mobility and lower } \\
\text { capital costs }\end{array}$ \\
\hline & Ecological fitness & $\begin{array}{l}\text { Situates production at supply locations when } \\
\text { renewable sources are ready to be processed }\end{array}$ \\
\hline & Scalable sustainability & $\begin{array}{c}\text { Overcomes common need for adaptability to depend } \\
\text { upon having redundancies in networks }\end{array}$ \\
\hline \multirow{3}{*}{ Enablers } & Mobile linking organisms & $\begin{array}{l}\text { Provides diverse options for development and } \\
\text { evolution, while located in accordance with planned } \\
\text { schedules or in response to unexpected events due to, } \\
\text { for example, weather or conflict }\end{array}$ \\
\hline & Energetics & $\begin{array}{l}\text { Increases the scope and the efficiency of energy flows } \\
\text { through deployment of solar-powered production } \\
\text { processes wherever they are needed }\end{array}$ \\
\hline & Ecosystem engineering & $\begin{array}{l}\text { Does not require overriding the natural evolutionary } \\
\text { balance of equal ecological fitness among a wide } \\
\text { variety of groups by increasing the number of fitness } \\
\text { components needed for survival }\end{array}$ \\
\hline
\end{tabular}

\subsection{Directions for Further Research}

One direction for future research is to investigate potential for the incorporation of ecological perspectives of social sustainability into recent initiatives such as inclusive manufacturing, which are aligned with the United Nations' Sustainable Development Goal 9 that advocates inclusive sustainable industrialization $[89,90]$.

Another direction for future research is to investigate the potential for moveable production technologies to bring production facilities to populations that forced to move through combinations of climate-related environmental changes [91-94]. For example, climate-related increases in sea levels can lead to population dispersal pressures due to higher incidence of waterborne infectious diseases [95], as well as due to land becoming uninhabitable as it is submerged [96]. During such future research, it will be important to consider that the widespread introduction of moveable production technologies could unintentionally destabilize or increase complexity through introducing too many strong links between diverse production operations. Accordingly, there should be a combination of few strong links and many weak links, which can foster a combination efficiency and adaptability [97-99]. For example, moveable solar-powered water sanitation units should have strong links to the few types of moveable production that need clean water and can be carried out throughout the year, such as local textile apparel production. At the same type, they should have weak links to many types of moveable production that need clean water occasionally at different times of the year, such as seasonal local agricultural production. Ideally, the introduction of moveable production technologies should support the emergence of simplicity rather than the growth of complexity. Such emergence can be found in the elegant functioning of natural systems and involves reduction of the variables to set or control parameters $[100,101]$. Accordingly, an important direction for action research is to determine how to combine moveable production technologies with local production capabilities in order to support emergence of simplicity rather than growth of complexity.

A third direction for future research is to investigate the extent to which microeconomic mutualistic relationships between many companies in different countries can be bring macroeconomic mutualistic relationship between countries. For example, large government subsidies of specific types of production in one country could limit potential for mutualistic relationships with other countries.

A fourth direction for future research is to examine the potential for mutualistic international production relationships and moveable production technologies to contribute to a shift towards 
world-fit production, that is, production that prioritizes multi-species ecological fitness over the current priorities of world-class production such as maximizing production productivity for the benefit of humans. A first question to address in such research is whether it is possible for human production of physical goods to ever to be compatible with multi-species ecological fitness rather than being compatible increasing the fitness of some human populations at the expense of many other species. For example, according to the United Nations, up to one million plant and animal species face extinction because of human activities [102]. Hence, the potential for world-fit production is an important research topic, which could encompass evaluation of the potential advantages and limitations of moveable production technologies.

\section{Conclusions}

In this paper, findings have been reported from action research carried out over seven years from 2013 to 2020. The objectives of the action research were to bring about two interrelated changes. They are (i) to introduce business interaction procedures that are accessible to both Finnish companies and Somali companies, which then (ii) lead to increased mutualistic business interactions between the two countries that can generate employment in both countries and increase the provision of essential goods in Somalia. Thus, the objectives of the action research were directed to addressing harm in current international production, which is dominated by world-class manufacturers that decide where and where not production will be carried out. The action research reported in Section 4 indicates that procedures for fostering mutualistic production relationships can be established between very different human geographies such as those of a rich European country and an African fragile state. Furthermore, the ecological analysis in Section 5 indicates that moveable production technologies offer many advantages for mutualistic production relationships. Together, more mutualistic business relationships and moveable production technologies that better enable mutualism can increase the social sustainability of international production involving diverse human geographies. Importantly, mutualistic business relationships and moveable production technologies can provide a timely alternative to conventional fixed production when human populations are moving to new geographies due to, for example, climate-related environmental changes [74-79].

Author Contributions: S.F.: conceptualization, action research, ecological analyses, and writing. Y.M.: action research reported in Section 4. A.A.: action research reported in Section 4. All authors have read and agreed to the published version of the manuscript.

Funding: Partial funding for research and writing was provided by the VTT GG_NPS project. Funding for meetings and associated travel described in Section 4 was provided by Finland-Somalia Association and by the Finnpartnership programme of the Finnish Foreign Ministry.

Conflicts of Interest: The authors declare no conflict of interest.

\section{References}

1. Bronstein, J.L. Mutualism; Oxford University Press: Oxford, UK, 2015.

2. Mawdsley, E. Development geography 1: Cooperation, competition and convergence between 'North' and 'South'. Prog. Hum. Geogr. 2017, 41, 108-117. [CrossRef]

3. Mahoney, J.; Rodríguez-Franco, D. Dependency theory. In The Oxford Handbook of the Politics of Development; Lancaster, C., van de Walle, N., Eds.; Oxford University Press: Oxford, UK, 2018; pp. $22-42$.

4. Baldwin, R. Trade and industrialization after globalization's second unbundling: How building and joining a supply chain are different and why it matters. In Globalization in an Age of Crisis: Multilateral Economic Cooperation in the Twenty-First Century; Feenstra, R.C., Taylor, A.M., Eds.; University of Chicago Press: Chicago, IL, USA, 2013; pp. 165-212.

5. Rodrik, D. Premature deindustrialization. J. Econ. Growth 2016, 21, 1-33. [CrossRef]

6. Schonberger, R.J. World Class Manufacturing; The Free Press, Macmillan Inc.: New York, NY, USA, 2008.

7. Petrillo, A.; De Felice, F.; Zomparelli, F. Performance measurement for world-class manufacturing: A model for the Italian automotive industry. Total Qual. Manag. Bus. Excell. 2019, 30, 908-935. [CrossRef] 
8. Dubey, R.; Gunasekaran, A.; Chakrabarty, A. World-class sustainable manufacturing: Framework and a performance measurement system. Int. J. Prod. Res. 2015, 53, 5207-5223. [CrossRef]

9. Grabowski, R. Premature deindustrialization and inequality. Int. J. Soc. Econ. 2017, 44, 154-168. [CrossRef]

10. Greenstein, J.; Anderson, B. Premature deindustrialization and the defeminization of labor. J. Econ. Issues 2017, 51, 446-457. [CrossRef]

11. Musaazi, M.K.; Mechtenberg, A.R.; Nakibuule, J.; Sensenig, R.; Miyingo, E.; Makanda, J.V.; Hakimien, A.; Eckelman, M.J. Quantification of social equity in life cycle assessment for increased sustainable production of sanitary products in Uganda. J. Clean. Prod. 2015, 96, 569-579. [CrossRef]

12. Ogar, J.N.; Nwoye, L.; Bassey, S.A. Archetype of globalization: Illusory comfort of neo-colonialism in Africa. Int. J. Humanit. Innov. 2019, 2, 90-95.

13. Langan, M. Neo-Colonialism and foreign corporations in Africa. In Neo-Colonialism and the Poverty of 'Development' in Africa; Contemporary African Political Economy; Palgrave Macmillan: Cham, Switzerland, 2018; pp. 33-60.

14. Alana, J.E.; Slater, T.; Bucknam, A. Action Research for Business, Nonprofit, and Public Administration-A Tool for Complex Times; Sage: Thousand Oaks, CA, USA, 2011.

15. Beckage, B.; Gross, L.J.; Kauffman, S. The limits to prediction in ecological systems. Ecosphere 2011, 2, 1-12. [CrossRef]

16. Kauffman, S. Innovation and the evolution of the economic web. Entropy 2019, 21, 864. [CrossRef]

17. Odowa, A.M. State-Society Relations and State Capacity in Somalia. In The Governance, Security and Development Nexus; Omeje, K., Ed.; Palgrave Macmillan: Cham, Switzerland, 2020; pp. 273-293.

18. Maliranta, M.; Valmari, N. The Renewal of Production at the Product Line Level in Finnish Manufacturing; ETLA Reports 72; The Research Institute of the Finnish Economy: Helsinki, Finland, 2017.

19. Randa, J.; Waheed, H.A. Somalia Economic Update, 4th ed.; The World Bank: Washington, DC, USA, 2019.

20. Messner, J.J.; Fiertz, C.; Haken, N.; Taft, P.; Blyth, H.; Maglo, M.; Moges, D.; Murphy, C.; Wilson, W.; Quinn, A.; et al. Fragile States Index Annual Report 2019; The Fund for Peace: Washington, DC, USA, 2019.

21. Patton, M.Q. Towards utility in reviews of multivocal literatures. Rev. Educ. Res. 1991, 61, 287-292. [CrossRef]

22. Patton, M.Q. Qualitative Research and Evaluation Methods, 3rd ed.; Sage Publications: Thousand Oaks, CA, USA, 2002.

23. Powney, J.; Watts, M. Interviewing in Education Research; Routledge \& Kegan Paul: London, UK, 1987.

24. Vidino, L.; Pantucci, R.; Kohlmann, E. Bringing Global Jihad to the Horn of Africa: Al Shabaab, western fighters, and the sacralization of the Somali Conflict. Afr. Secur. 2010, 3, 216-238. [CrossRef]

25. Frank, A.G. The development of underdevelopment. Mon. Rev. 1989, 41, 37-52. [CrossRef]

26. Bunker, S.G. Underdeveloping the Amazon: Extraction, Unequal Exchange, and the Failure of the Modern State; University of Ilinois Press: Urbana, IL, USA, 1985.

27. Wallerstein, I.M.; Wallerstein, S.R.I. World-Systems Analysis: An Introduction; Duke University Press: Durham, BC, USA, 2004.

28. Mason, R. China's impact on the landscape of African International Relations: Implications for dependency theory. Third World Q. 2017, 38, 84-96. [CrossRef]

29. Maswana, J.C. Colonial patterns in the growing Africa and China interaction: Dependency and trade intensity perspectives. J. Pan Afr. Stud. 2015, 8, 95-112.

30. Bunker, S.G. Raw materials and global economy: Oversights and distortions in industrial ecology. Soc. Nat. Resour. 1996, 9, 419-429. [CrossRef]

31. Hornborg, A. Ecosystems and world-systems: Accumulation as an ecological process. In Global Social Change: Historical and Comparative Perspectives; Chase-Dunn, C., Babones, S.J., Eds.; John Hopkins University Press: Baltimore, MD, USA, 2006; pp. 161-175.

32. Moore, J.W. Ecology, capital, and the nature of our times: Accumulation \& crisis in the capitalist world-ecology. J. World Syst. Res. 2011, 17, 107-146.

33. Rice, J. Ecological unequal exchange: International trade and uneven utilization of environmental space in the world system. Soc. Forces 2007, 85, 1369-1392. [CrossRef]

34. Littig, B.; Griessler, E. Social sustainability: A catchword between political pragmatism and social theory. Int. J. Sustain. Dev. 2005, 8, 65-79. [CrossRef]

35. Khan, M.; Hussain, M.; Gunasekaran, A.; Ajmal, M.; Helo, P. Motivators of social sustainability in healthcare supply chains in the UAE-Stakeholder perspective. Sustain. Prod. Consum. 2018, 14, 95-104. [CrossRef] 
36. Pinzone, M.; Albè, F.; Orlandelli, D.; Barletta, I.; Berlin, C.; Johansson, B.; Taisch, M. A framework for operative and social sustainability functionalities in Human-Centric Cyber-Physical Production Systems. Comput. Ind. Eng. 2020, 139, 105132. [CrossRef]

37. Roca-Puig, V. The circular path of social sustainability: An empirical analysis. J. Clean. Prod. 2019, 212, 916-924. [CrossRef]

38. Missimer, M.; Robèrt, K.H.; Broman, G. A strategic approach to social sustainability-Part 1: Exploring the social system. J. Clean. Prod. 2017, 140, 32-41. [CrossRef]

39. Ahmadi, H.B.; Kusi-Sarpong, S.; Rezaei, J. Assessing the social sustainability of supply chains using Best Worst Method. Resour. Conservat. Recycl. 2017, 126, 99-106. [CrossRef]

40. Mani, V.; Gunasekaran, A.; Delgado, C. Enhancing supply chain performance through supplier social sustainability: An emerging economy perspective. Int. J. Prod. Econ. 2018, 195, 259-272. [CrossRef]

41. Bhaskar, R. Forms of Realism. Philosophica 1975, 15, 99-127.

42. Mingers, J. Systems Thinking, Critical Realism and Philosophy: A Confluence of Ideas. In Ontological Explorations; Routledge: London, UK, 2014.

43. Schlechtendahl, J.; Keinert, M.; Kretschmer, F.; Lechler, A.; Verl, A. Making existing production systems Industry 4.0-ready. Prod. Eng. 2015, 9, 143-148. [CrossRef]

44. Thoben, K.D.; Wiesner, S.; Wuest, T. "Industrie 4.0” and smart manufacturing-a review of research issues and application examples. Int. J. Autom. Technol. 2017, 11, 4-16. [CrossRef]

45. Brown, J.H.; Hall, C.A.; Sibly, R.M. Equal fitness paradigm explained by a trade-off between generation time and energy production rate. Nat. Ecol. Evol. 2018, 2, 262-268. [CrossRef]

46. Siepielski, A.M.; DiBattista, J.D.; Evans, J.A.; Carlson, S.M. Differences in the temporal dynamics of phenotypic selection among fitness components in the wild. Proc. R. Soc. Biol. Sci. 2011, 278, 1572-1580. [CrossRef]

47. Schweder, J. Turning out lights on the factory floor. Autom. World 2017, 22. Available online: https://www.automationworld.com/factory/robotics/article/13316849/turning-out-the-lights-on-thefactory-floor (accessed on 14 October 2020).

48. African Union Directorate of Information and Communication. Press Release No. 331/2015; Africa-EU Migration Summit in Valletta, Malta; African Union Directorate of Information and Communication: Addis Ababa, Ethiopia, 2015.

49. Ibrahim, A.Y. Determinants of youth emigration in Somalia. Strategic. J. Bus. Chang. Manag. 2018, 5, 984-1003.

50. Maher, S. Out of West Africa: Human smuggling as a social enterprise. Ann. Am. Acad. Political Soc. Sci. 2018, 676, 36-56. [CrossRef]

51. Reitano, T. Smugglers Inc.: The Illicit Industry in Human Migration. In Militarised Responses to Transnational Organised Crime; Reitano, T., Jesperson, S., Bird Ruiz-Benitez de Lugo, L., Eds.; Palgrave Macmillan: Cham, Switzerland, 2018.

52. Fox, S. Moveable production systems for sustainable development and trade: Limitations, opportunities, and barriers. Sustainability 2019, 11, 5154. [CrossRef]

53. Admiraal, J.F.; Wossink, A.; de Groot, W.T.; de Snoo, G.R. More than total economic value: How to combine economic valuation of biodiversity with ecological resilience. Ecol. Econ. 2013, 89, 115-122. [CrossRef]

54. Lundberg, J.; Moberg, F. Mobile link organisms and ecosystem functioning: Implications for ecosystem resilience and management. Ecosystems 2003, 6, 87-98. [CrossRef]

55. Maystadt, J.F.; Ecker, O. Extreme weather and civil war: Does drought fuel conflict in Somalia through livestock price shocks? Am. J. Agric. Econ. 2014, 96, 1157-1182. [CrossRef]

56. Kauffman, S.A. Prolegomenon to patterns in evolution. Biosystems 2014, 123, 3-8. [CrossRef]

57. Buenstorf, G. Self-organization and sustainability: Energetics of evolution and implications for ecological economics. Ecol. Econ. 2000, 33, 119-134. [CrossRef]

58. Layman, C.A.; Quattrochi, J.P.; Peyer, C.M.; Allgeier, J.E. Niche width collapse in a resilient top predator following ecosystem fragmentation. Ecol. Lett. 2007, 10, 937-944. [CrossRef]

59. Peacock, K.A. The three faces of ecological fitness. Stud. Hist. Philos. Biol. Biomed. Sci. 2011, 42, 99-105. [CrossRef]

60. Jones, C.G.; Lawton, J.H.; Shachak, M. Positive and negative effects of organisms as physical ecosystem engineers. Ecology 1997, 78, 1946-1957. [CrossRef] 
61. Waters, C.N.; Zalasiewicz, J.; Summerhayes, C.; Barnosky, A.D.; Poirier, C.; Gałuszka, A.; Cearreta, A.; Edgeworth, M.; Ellis, E.C.; Ellis, M.; et al. The Anthropocene Is Functionally and Stratigraphically Distinct from the Holocene. Science 2016, 351, 2622. [CrossRef]

62. Birch, J. Natural selection and the maximization of fitness. Biol. Rev. 2016, 91, 712-772. [CrossRef]

63. Ronce, O. How does it feel to be like a rolling stone? Ten questions about dispersal evolution. Annu. Rev. Ecol. Evol. Syst. 2007, 38, 231-253. [CrossRef]

64. Eilam, D. Die hard: A blend of freezing and fleeing as a dynamic defense-Implications for the control of defensive behavior. Neurosci. Biobehav. Rev. 2005, 29, 1181-1191. [CrossRef]

65. Rushton, J.P. Inclusive fitness in human relationships. Biol. J. Linn. Soc. 2008, 96, 8-12. [CrossRef]

66. Liu, J.; Dietz, T.; Carpenter, S.R.; Alberti, M.; Folke, C.; Moran, E.; Pell, A.N.; Deadman, P.; Kratz, T.; Lubchenco, J.; et al. Complexity of Coupled Human and Natural Systems. Science 2007, 317, 1513-1516. [CrossRef]

67. Kharrazi, A.; Rovenskaya, E.; Fath, B.D.; Yarime, M.; Kraines, S. Quantifying the sustainability of economic resource networks: An ecological information-based approach. Ecol. Econ. 2013, 90, 177-186. [CrossRef]

68. Roli, A.; Villani, M.; Filisetti, A.; Serra, R. Dynamical Criticality: Overview and open questions. J. Syst. Sci. Complex. 2018, 31, 647-663. [CrossRef]

69. Ulanowicz, R.E. Ecology, the Ascendent Perspective; Columbia University Press: New York, NY, USA, 1997.

70. Mayer, A.L.; Donovan, R.P.; Pawlowski, C.W. Information and entropy theory for the sustainability of coupled human and natural systems. Ecol. Soc. 2014, 19, 11. [CrossRef]

71. Ivanov, D.; Sokolov, B.; Dolgui, A. The Ripple effect in supply chains: Trade-off 'efficiency-flexibility-resilience' in disruption management. Int. J. Prod. Res. 2014, 52, 2154-2172. [CrossRef]

72. Kummel, M.; Salant, S.W. The economics of mutualisms: Optimal utilization of mycorrhizal mutualistic partners by plants. Ecology 2006, 87, 892-902. [CrossRef]

73. Azapagic, A.; Stamford, L.; Youds, L.; Barteczko-Hibbert, C. Towards sustainable production and consumption: A novel decision-support framework integrating economic, environmental and social sustainability (DESIRES). Comput. Chem. Eng. 2016, 91, 93-103. [CrossRef]

74. Mota, B.; Gomes, M.I.; Carvalho, A.; Barbosa-Povoa, A.P. Towards supply chain sustainability: Economic, environmental and social design and planning. J. Clean. Prod. 2015, 105, 14-27. [CrossRef]

75. Costanza, R. Ecological Economics: The Science and Management of Sustainability; Columbia University Press: New York, NY, USA, 1992.

76. Van den Bergh, J.C. Ecological economics: Themes, approaches, and differences with environmental economics. Reg. Environ. Chang. 2001, 2, 13-23. [CrossRef]

77. Saravia-Cortez, A.M.; Herva, M.; García-Diéguez, C.; Roca, E. Assessing environmental sustainability of particleboard production process by ecological footprint. J. Clean. Prod. 2013, 52, 301-308. [CrossRef]

78. Wang, Z.; Yang, L.; Yin, J.; Zhang, B. Assessment and prediction of environmental sustainability in China based on a modified ecological footprint model. Resour. Conserv. Recycl. 2018, 132, 301-313. [CrossRef]

79. Kun, Á.; Oborny, B.; Dieckmann, U. Five main phases of landscape degradation revealed by a dynamic mesoscale model analysing the splitting, shrinking, and disappearing of habitat patches. Sci. Rep. 2019, 9, 11149. [CrossRef]

80. Bluestone, B.; Harrison, B. The Deindustrialization of America: Plant Closings, Community Abandonment, and the Dismantling of Basic Industry; Basic Books: New York, NY, USA, 1982; Volume 312.

81. Matthews, R.A.; Maume, M.O.; Miller, W.J. Deindustrialization, economic distress, and homicide rates in midsized Rustbelt cities. Homicide Stud. 2001, 5, 83-113. [CrossRef]

82. Carling, J.; Collins, F. Aspiration, desire and drivers of migration. J. Ethn. Migr. Stud. 2018, 44, 909-926. [CrossRef]

83. McLean, K. "There's nothing here": Deindustrialization as risk environment for overdose. Int. J. Drug Policy 2016, 29, 19-26. [CrossRef] [PubMed]

84. Caraballo-Cueto, J.; Lara, J. Deindustrialization and unsustainable debt in middle-income countries: The case of Puerto Rico. J. Glob. Dev. 2007, 8, 1-11. [CrossRef]

85. Schindler, S.; Gillespie, T.; Banks, N.; Bayırbağ, M.K.; Burte, H.; Kanai, J.M.; Sami, N. Deindustrialization in cities of the Global South. Area Dev. Policy 2020, 5. [CrossRef]

86. Scherrer, $\mathrm{C}$. The disrupted passage from an agrarian rural to an industrial urban workforce in most countries in the Global South. J. Political Econ. 2018, 7, 301-319. 
87. Albahari, M. From right to permission: Asylum, Mediterranean migrations, and Europe's war on smuggling. J. Migr. Hum. Secur. 2018, 6, 121-130. [CrossRef]

88. Hale, K.R.; Valdovinos, F.S.; Martinez, N.D. Mutualism increases diversity, stability, and function of multiplex networks that integrate pollinators into food webs. Nat. Commun. 2020, 11, 1-14. [CrossRef]

89. NIAS. Inclusive Manufacturing Forum Report 2018; National Institute of Advanced Studies: Bangaluru, India, 2018.

90. WMF. World Manufacturing Forum Report, Recommendations for the Future of Manufacturing. 2018. Available online: https://docs.wixstatic.com/ugd/03d390_b6ae0b7ab0da48ca90903b3817be00e6.pdf (accessed on 17 September 2020).

91. Huang, J.; Zhang, G.; Zhang, Y.; Guan, X.; Wei, Y.; Guo, R. Global desertification vulnerability to climate change and human activities. Land Degrad. Dev. 2020, 31. [CrossRef]

92. Patton, A.I.; Rathburn, S.L.; Capps, D.M. Landslide response to climate change in permafrost regions. Geomorphology 2019, 340, 116-128. [CrossRef]

93. Boer, M.M.; de Dios, V.R.; Bradstock, R.A. Unprecedented burn area of Australian mega forest fires. Nat. Clim. Chang. 2020, 10, 171-172. [CrossRef]

94. Wu, X.; Lu, Y.; Zhou, S.; Chen, L.; Xu, B. Impact of climate change on human infectious diseases: Empirical evidence and human adaptation. Environ. Int. 2016, 86, 14-23. [CrossRef] [PubMed]

95. Chowdhury, F.R.; Ibrahim, Q.S.U.; Bari, M.S.; Alam, M.J.; Dunachie, S.J.; Rodriguez-Morales, A.J.; Patwary, M.I. The association between temperature, rainfall and humidity with common climate-sensitive infectious diseases in Bangladesh. PLoS ONE 2018, 13, e0199579. [CrossRef] [PubMed]

96. Wrathall, D.J.; Mueller, V.; Clark, P.U.; Bell, A.; Oppenheimer, M.; Hauer, M.; Abel, K. Meeting the looming policy challenge of sea-level change and human migration. Nat. Clim. Chang. 2019, 9, 898-901. [CrossRef]

97. McCann, K.; Hastings, A.; Huxel, G.R. Weak trophic interactions and the balance of nature. Nature 1998, 395, 794. [CrossRef]

98. Olesen, J.M.; Bascompte, J.; Dupont, Y.L.; Elberling, H.; Rasmussen, C.; Jordano, P. Missing and forbidden links in mutualistic networks. Proc. R. Soc. Biol. 2011, 278, 725-732. [CrossRef]

99. Ulanowicz, R.E.; Goerner, S.J.; Lietaer, B.; Gomez, R. Quantifying sustainability: Resilience, efficiency and the return of information theory. Ecol. Complex. 2009, 6, 27-36. [CrossRef]

100. Pham, T.D.; Elfiqi, H.Z.; Knecht, S.; Wersching, H.; Baune, B.T.; Berger, K. Structural simplexity of the brain. J. Neurosci. Meth. 2010, 188, 113-126. [CrossRef]

101. Tworek, K.; Walecka-Jankowska, K.; Zgrzywa-Ziemak, A. Towards organisational simplexity-A simple structure in a complex environment. Eng. Manag. Prod. Serv. 2019, 11, 43-53. [CrossRef]

102. Tollefson, J. One million species face extinction. Nature 2019, 569, 171. [CrossRef]

Publisher's Note: MDPI stays neutral with regard to jurisdictional claims in published maps and institutional affiliations.

(C) 2020 by the authors. Licensee MDPI, Basel, Switzerland. This article is an open access article distributed under the terms and conditions of the Creative Commons Attribution (CC BY) license (http://creativecommons.org/licenses/by/4.0/). 